\title{
Increasing Recombinant Protein Production in E. coli by an Alternative Method to Reduce Acetate
}

\author{
Hendrik Waegeman and Marjan De Mey \\ Ghent University, Centre of Expertise-Industrial Biotechnology and Biocatalysis, \\ Belgium
}

\section{Introduction}

Since the development of recombinant DNA technology (Cohen et al., 1973), it became possible to express heterologous genes in pro- or eukaryotic hosts, i.e. genes which they naturally not express. This development enabled the production of all kinds of products of which the high-added value recombinant proteins, became increasingly important and as such boosted biopharmaceutical and industrial enzyme applications. Up to now, the FDA (Food and Drug Administration) and EMEA (European Medicines Agency) have licensed the application of more than 150 recombinant proteins to be used as a pharmaceutical (Ferrer-Miralles et al., 2009). Global sales of biopharmaceuticals are estimated to account for US\$70-80 Billion today (Walsh, 2010). Industrial enzymes (e.g. proteases, amylases, lipases, cellulases, pullulanases, pectinases) are used in various industrial segments and the industrial enzyme market is still expanding, estimated to reach US\$ 3.74 Billion by the year 2015 (Global Industry Analysts, 2011). To date, the majority of this industrial enzyme market value is generated by recombinant processes (Hodgson, 1994; Demain \& Vaishnav, 2009).

It is clear that recombinant protein production has evolved to one of the most important branches in modern biotechnology, representing a billion-dollar business, both in the production of biopharmaceuticals and industrial enzymes.

A pivotal choice in the design of a recombinant protein bioprocess is the selection of a suitable host strain. This selection is influenced by different factors: (i) ease of cultivation and growth characteristics, (ii) ease of genetic manipulation and availability of molecular tools, (iii) ability of post-translational modifications (e.g. glycosylation patterns, disulfide bond formation), (iv) downstream processing, and (v) regulatory aspects (generally regarded as safe, SAFE (Lotti et al., 2004; Sahdev et al., 2008; Durocher \& Butler, 2009).

These aspects will determine whether the designed recombinant protein bioprocess will end up in an economical viable bioprocess which can compete with the present process.

In contrast to biopharmaceuticals, industrial enzyme bioprocesses are only economical viable as a low production cost is assured. This implies that higher yields, titres and 
production rates are necessary which can only be obtained by fast growing organisms. This is reflected by the distribution of the most commonly used organisms in these two industries. Whereas slow growing organisms as plants and animals are used as host in half of the biopharmaceutical processes, they count only for $12 \%$ of the processes in the industrial enzyme market (Demain \& Vaishnav, 2009; Ferrer-Miralles et al., 2009). Bacteria on the other hand, have a market share of $30 \%$ in both industries. However, yeasts and molds, which grow much faster in comparison with higher eukaryotes, are used in $58 \%$ of the cases in the industrial enzyme market and only in $18 \%$ of the cases in the in the biopharmaceutical market.

Several bacteria have been explored as host for recombinant protein production. Recently, much interest is raised in the use of Bacillus strains as host for recombinant protein production because of their advantageous features as gram-positive (Terpe, 2006). However, till today Escherichia coli remains a very popular and predominantly used bacterium for recombinant protein production. This is primarily because this well-characterised organism can easily and rapidly grow on cheap substrates and can be simply modified through a broad variety of molecular tools. But even more, the further exploration of other potential microbial hosts are often restricted due to limited information about genetics and metabolism and/or the availability of molecular tools.

\section{Escherichia coli for recombinant protein production}

Besides the advantage of many available molecular tools, the easily cultivable and genetically and metabolically well-known Escherichia coli can be grown to high biomass concentrations in high cell density cultures allowing the production of high amounts of heterologous protein (Makrides, 1996). Nonetheless, E. coli suffers from some major drawbacks as well.

i. The production of heterologous proteins to high titres concurs mostly with the initiation of a stress response and/or metabolic burden, both associated with the use of multicopy plasmids, resulting in misfolding and degradation of the heterologous protein and formation of inclusion bodies (Noack et al., 1981; Parsell \& Sauer, 1989; Bentley et al., 1990; Gill et al., 2000; Hoffmann \& Rinas, 2004; Ventura \& Villaverde, 2006).

ii. As prokaryotic, Escherichia coli lacks the ability to perform enhanced post-translational modifications making the production of more complex eukaryotic proteins in E. coli challenging. This inability to form disulfide bonds or to execute glycosylation results in the production of instable and non-functional proteins.

iii. Secretory production of recombinant proteins into the culture medium includes several advantages, especially in cases of toxic recombinant proteins. However, compared to other hosts, E. coli does not naturally secrete proteins in high amounts. Nonetheless, E. coli possesses different secretions systems for the transport of proteins from the cytoplasmic to the perisplasmic or extracellular environment (Tseng et al., 2009). Crucial hereby is the signal peptide which is linked to the protein allowing recognition and transport by the secretion system.

iv. The main difficulty when using E. coli as host is the production of acetate as by-product during fermentations as a result of overflow metabolism occurring when cells grow 
rapidly and cannot metabolise the delivered carbon source fast enough (Andersen \& von Meyenburg, 1980; Holms, 1986). It is generally observed that even low concentrations of acetate can hamper growth and obstruct the production of recombinant proteins (Jensen \& Carlsen, 1990; Nakano et al., 1997).

Many efforts have been made to overcome these hurdles and hence to increase recombinant protein production in E. coli or to express more complex proteins in this host. These engineering attempts are summarized in Fig. 1.

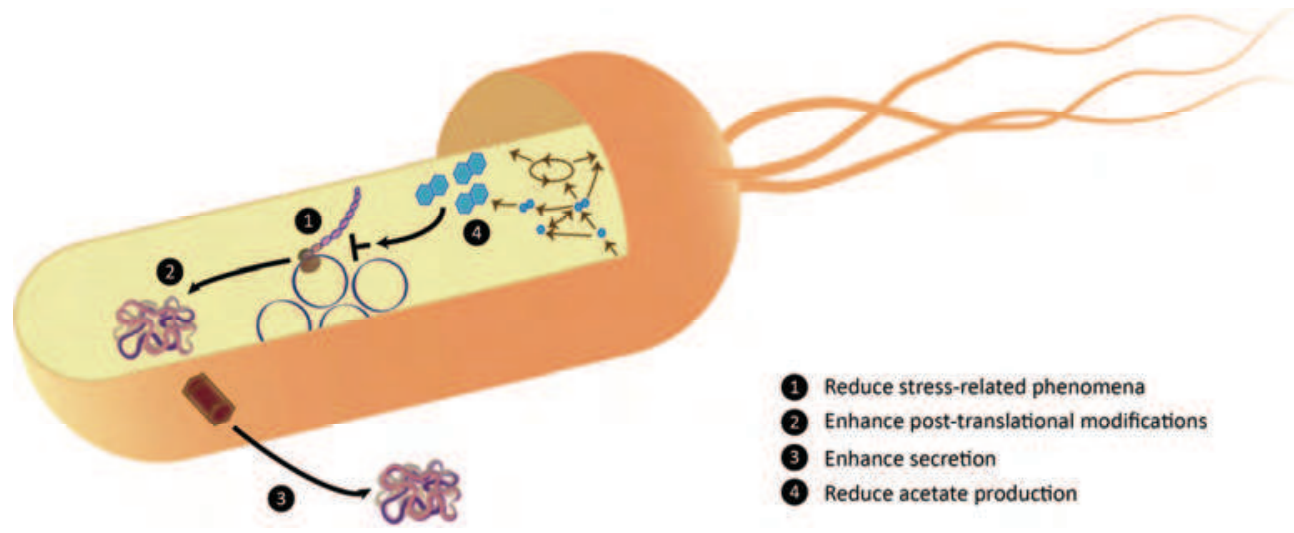

Fig. 1. Overview of different engineering approaches to increase recombinant protein production in Escherichia coli

The primarily used approach to produce recombinant proteins is to clone the gene of interest on a multi-copy plasmid under the control of a strong promoter in order to achieve high transcription rates and hence high recombinant protein concentrations. However, problems such as metabolic burden, segregational instability, misfolding and proteolytic breakdown or aggregation in inclusion bodies, and difficulties in controlling gene expression are usually associated with multi-copy plasmids and the use of strong promoters (Noack et al., 1981; Parsell \& Sauer, 1989; Bentley et al., 1990; Dong et al., 1995; Kurland \& Dong, 1996; Gill et al., 2000; Hoffmann \& Rinas, 2004; Ventura \& Villaverde, 2006). Most engineering strategies to tackle these problems focus on prevention of misfolding, neutralisation of increased protease activity or stress response (Chou, 2007). An elaborated review of these efforts is given in (Waegeman \& Soetaert, 2011).

Two post-translational modifications which are pivotal for the stability and activity of many more complex eukaryotic proteins are disulfide bonds and glycosylation. The former is being facilitated in E. coli by secreting the recombinant protein into the more oxidizing perisplasmic space using the Sec or Tat secretion system, by altering the redox state of the cytoplasm through modifications in the thioredoxin reductase gene $(\operatorname{tr} x B)$ and gluthatione reductase genes (gor) or by cytoplasmic overexpression of periplasmic disulfide oxidoreductases (such as DsbC) which enhance the rate of disulfide isomerisation. An excellent review of these engineering strategies can be found in (de Marco, 2009). 
Besides the proper formation of disulfide bonds, E. coli also lacks the ability of glycosylation.

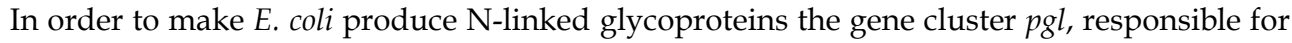
glycosylation in Campylobacter jejuni (Szymanski et al., 1999; Abu-Qarn et al., 2008) was successfully transferred (Wacker et al., 2002). Moreover, combination of the $p g l$ system with a simple, genetically encoded glycosylation tag, expands the glycosylation possibilities of $E$. coli (Fisher et al., 2011).

The secretory production of recombinant proteins into the fermentation broth includes several advantages compared to cytoplasmic production. Although E. coli has different secretion systems for transport of proteins, secretion of recombinant proteins is rather complex. Many research efforts focus on the utilisation of these existing transport routes for the secretion of heterlogous proteins (Choi \& Lee, 2004; Jong et al., 2010) including selection and modification of the signal peptide, coexpression of proteins that assist in translocation and folding, improvement of periplasmic release when transport occurs in two steps or protection of the target protein from degradation and contamination (Abdallah et al., 2007).

\section{An alternative approach to reduce acetate production and improve recombinant protein production in Escherichia coli}

Throughout the years, various Escherichia coli strains with different genotypes have been examined for their potential to produce recombinant proteins in high titres. A comprehensive overview of all E. coli strains used in recombinant protein production processes and their characteristics is given in (Waegeman \& Soetaert, 2011). Although E. coli $\mathrm{B}$ and $E$. coli $\mathrm{K} 12$ strains are equally used as host for recombinant protein production (47\% and $53 \%$, respectively), E. coli BL21 is by far the most commonly used strain (35\%) in academia. In industry, this number is probably even much higher.

Escherichia coli BL21 displays higher biomass yields compared to E. coli K12 resulting in substantially lower acetate amounts which in return has a positive effect on the recombinant protein production (El-Mansi \& Holms, 1989; Shiloach et al., 1996). The second reason of the extensive use of E. coli BL21 as microbial host for recombinant protein production is that this strain is deficient in the proteases Lon and OmpT, which decreases the breakdown of recombinant protein and result in higher yields (Gottesman, 1989; Gottesman, 1996). However, until recently the genome sequence of E. coli BL21 was not available making genetically modifications not always straightforward and therefore challenging. Consequently, still a lot of attention and effort is going towards E. coli K12-derived strains as most favourable E. coli strain for recombinant protein production (Ko et al., 2010; Ryu et al., 2010; Striedner et al., 2010).

Many different strategies have been applied to increase recombinant protein formation and decrease acetate formation in E. coli K12 strains including optimisation of the bioprocess conditions as metabolic engineering of the production host (De Mey et al., 2007b). These approaches comprise attempts which can be categorised in 3 classes: (i) deletion of acetate pathway genes, (ii) avoiding overflow metabolism by limiting the glucose uptake system through alteration of the carbon source, applying elaborate feeding strategies, or engineering the glucose uptake system, and (iii) avoiding overflow metabolism by redirecting central metabolic fluxes and preserving sufficient precursors of the amino acids, the building blocks of proteins (Fig. 2). 


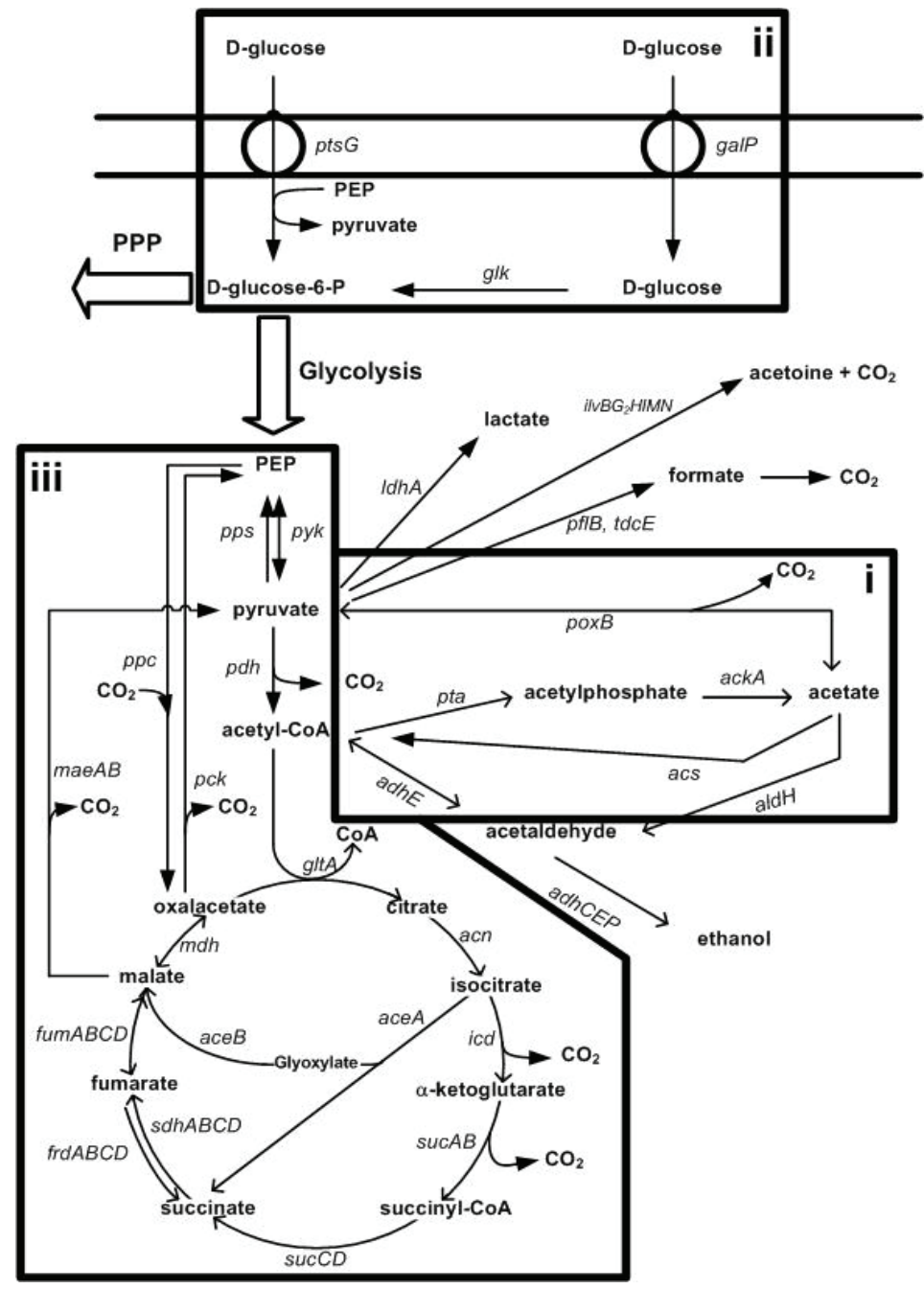

Fig. 2. Strategies to reduce acetate formation in Escherichia coli (adapted from Waegeman \& Soetaert, 2011): (i) blocking the acetate pathway by knocking out genes that encode for acetate pathway enzymes, (ii) reducing the glucose uptake rate, and (iii) redirecting central metabolic fluxes. PPP, pentose phosphate pathway; ace $A$, isocitrate lyase; $a c e B$, malate synthase; $a c k A$, acetate kinase; $a c n$, aconitase; acs, acetyl-CoA synthase; adhCEP, ethanol dehydrogenase; $a d h E$, aldehyde dehydrogenase; fum $A B C D$, fumarase; galP, galactose permease; $g l k$, glucokinase; $i c d$, isocitrate dehydrogenase; ilv $B G_{2} H I M N$, acetolacetate decarboxylase; $l d h A$, lactate dehydrogenase; mae $A B$, malic enzyme; $m d h$, malate dehydrogenase; $p c k$, phosphoenolpyruvate carboxykinase; $p d h$, pyruvate dehydrogenase; $p f B, t d c E$, pyruvate formate lyase; $p o x B$, pyruvate oxidase; $p p c$, phosphoenolpyruvate carboxylase; $p p s$, phosphoenolpyruvate synthase; $p t a$, acetylphosphotransferase; $p y k$, pyruvate kinase; $s d h A B C D$, succinate dehydrogenase; $s u c A B$, a-ketoglutarate dehydrogenase; $s u c C D$, succinate thiokinase. 
The first, rational effort to decrease acetate production is to block the acetate pathway by knocking out genes that encode for acetate pathway enzymes, e.g. ackA (acetate kinase), pta (phosphate acetyltransferase) and poxB (pyruvate oxidase) (Diaz-Ricci et al., 1991; Yang et al., 1999; Contiero et al., 2000; Dittrich et al., 2005; De Mey et al., 2007a). These attempts resulted in a considerably decrease of acetate production but in return pyruvate, lactate or formate formation, which are also undesired by-products, increased to a large extent.

A second widely followed approach to minimise acetate formation during high cell density fermentations is to limit rapid uptake of glucose causing overflow metabolism. Overflow metabolism occurs when high glycolytic fluxes, due to rapid glucose uptake, are not further processed in the TCA cycle developing a bottleneck at the pyruvate node and consequently pyruvate is converted to acetate.

Strategies based on optimising the bioprocess conditions to reduce the glucose uptake rate comprise applying specific glucose feeding patterns, the application of alternative substrates, the addition of supplements to the medium, the control of a range of fermentation parameters and the application of systems to remove acetate from the fermentation broth (Farmer \& Liao, 1997; Nakano et al., 1997; Akesson et al., 1999; Akesson et al., 2001b; Akesson et al., 2001a; Fuchs et al., 2002 ; Chen et al., 2005; Eiteman \& Altman, 2006). Although all these attempts were in many cases successful to reduce acetate production, they imply a severe lower growth rate and they do not utilise the full potential of the microbial host.

Engineering of the glucose uptake system is being successfully applied as well to overcome overflow metabolism. By deleting one of the phosphotransferase system genes, e.g. ptsG, $p t s H$ or $p t s I$, the uptake through the major glucose transporter is several impeded, resulting in a reduced glycolytic flux and reduced acetate pathway (Chou et al., 1994; Siguenza et al., 1999; De Anda et al., 2006; Wong et al., 2008). To restore the strong reduction in growth rate as consequence of hampering the main glucose transporter De Anda et al. (2006) overexpressed the alternative glucose transporter gene galP (coding for a galactose permease) and exploited the native glucose kinase (Glk) transporter. The resulting strain $E$. coli W3110 $\Delta$ ptsH galP+ displayed a very low acetate yield and a significantly increased recombinant protein yield compared to the E. coli W3110 wild-type, without reduction in growth rate. Wong et al (2008) restored glucose transport by co-expressing the gene $g l f$, encoding for a passive glucose transporter of Zymomonas mobilis. However, this only resulted in a decreased acetate formation in M9 minimal media, not in LB media.

A third approach to overcome overflow metabolism is to redirect the fluxes around the bottleneck, the phosphoenolpyruvate-pyruvate-oxaloacetate node, instead of restricting the glucose uptake. Farmer \& Liao (1997) increased anaplerotic and glycolate fluxes by overexpressing phosphenolpyruvate carboxylase (encoded by $p p c$ ) and by deleting the FadR regulator. This notable strategy resulted in a more than $75 \%$ decrease in acetate yield compared to its wild type. Alternatively, another important success was achieved by the overexpression of a heterologous anaplerotic pyruvate carboxylase from Rhizobium etli resulting in a $57 \%$ reduction in acetate formation and a $68 \%$ increase in recombinant protein production (March et al., 2002). Similarly, De Mey et al. (2010) achieved an increase in recombinant protein production by deleting the genes coding for acetate pathway enzymes combined with the overexpression of $p p c$. 
An alternative approach to enhance recombinant protein production is mimicking the E. coli BL21 phenotype in E. coli $\mathrm{K} 12$ by interfering on the regulatory level of gene expression instead of targeting genes directly involved in the conversion of metabolites in the acetate pathway our around the phosphoenolpyruvate-pyruvate-oxaloacetate node. ${ }^{13} \mathrm{C}$ metabolic flux analysis showed that the low acetate production in E. coli BL21(DE3) is caused by activation of the glyoxylate pathway (Noronha et al., 2000), a pathway which is normally not activated under glucose excess in E. coli K12 strains. Furthermore, acetate assimilation pathways are more active in E. coli BL21 compared to in E. coli K12 (Phue et al., 2005).

\subsection{Influence of transcriptional regulators ArcA and IcIR on Escherichia coli phenotypes}

Regulation of gene expression is very complex and transcriptional regulators can be subdivided in global and local regulators depending on the number of operons they control. Global regulators control a vast number of genes, which must be physically separated on the genome and belong to different metabolic pathways (Gottesman, 1984). According to EcoCyc (Keseler et al., 2011) E. coli K12 MG1655 contains 40 master regulators and sigma factors. Nonetheless, only seven global regulators control the expression of $51 \%$ of all genes: ArcA, Crp, Fis, Fnr, Ihf, Lrp and NarL. In contrast to global regulators, local regulators control only a few genes, e.g. $20 \%$ of all transcriptional regulators control the expression of only one or two genes (Martinez-Antonio \& Collado-Vides, 2003).

The global regulator ArcA (anaerobic redox control) was first discovered in 1988 by Iuchi and Lin and the regulator seemed to have an inhibitory effect on expression of aerobic TCA cycles genes under anaerobic conditions (Iuchi \& Lin, 1988). Later on, it was unravelled that Arc $A$ is a component of the dual-component regulator $A r c A B$, in which Arc $A$ is the regulatory protein and $A r c B$ acts as sensory protein (Iuchi et al., 1990).

Acording to EcoCyc (Keseler et al., 2011) ArcA is involved in the regulation of 168 genes and itself is regulated by 2 regulators (FnrR, RpoD). Statistical analysis of gene expression data (Salmon et al., 2005) showed that ArcA regulates the expression of a wide variety of genes involved in the biosynthesis of small macromolecules, transport, carbon and energy metabolism, cell structure, etc. The regulatory activity of ArcA is dependent on the oxygen concentration in the environment. The most profound effects of ArcA are noticed under microaerobic conditions (Alexeeva et al., 2003) but recently it was reported that also under aerobic conditions ArcA has an effect on central metabolic fluxes (Perrenoud \& Sauer, 2005).

Similarly to the global transcriptional regulator ArcA, the local transcriptional regulator isocitrate lyase regulator IclR has a reductive effect on the flux through the TCA cycle (Rittinger et al., 1996). IclR represses the expression of the aceBAK operon, which codes for the glyoxylate pathway enzymes isocitrate lyase (encoded by ace $A$ ), malate synthase (encoded by $a c e B$ ), and isocitrate dehydrogenase kinase/phosphatise (encoded by aceK) (Yamamoto \& Ishihama, 2003). The last enzyme phosphorylates the TCA cycle enzyme isocitrate dehydrogenase (Icd) controlling the switch between the flux through the TCA cycle and the glyoxylate pathway. It is reported that when IclR levels are low or when IclR is inactivated, i.e. for cells growing on acetate (Cortay et al., 1991; Cozzone, 1998; El-Mansi et al., 2006), or in slow growing glucose utilising cultures (Fischer \& Sauer, 2003; Maharjan et al., 2005), repression on glyoxylate genes is released and the glyoxylate pathway is activated. 
As both transcriptional regulators, ArcA and IclR, are involved in controlling the flux through the TCA cycle and glyoxylate pathway, they are interesting targets for metabolic engineering for mimicking the E. coli BL21 phenotype in E. coli K12.

To investigate their effect, single knockouts as a knockout combination were made in $E$. coli MG1655 (K12-strain). The different mutants and wild type were cultivated in a 2L stirred tank bioreactor under glucose abundant (batch cultivation) conditions in order to precisely determine extracellular fluxes and growth rates and consequently to evaluate the physiological and metabolic consequences of $\operatorname{arcA}$ and $i c l R$ deletions on E. coli MG1655. In order to evaluate if these effects are corresponding with the characteristics of E. coli BL21, this E. coli strain was also tested. The growth rates and the average carbon and redox balances of the different strains are shown in Table 1.

\begin{tabular}{cccc}
\hline E. coli strain & $\mu_{\max }\left(\mathbf{h}^{-1}\right)$ & Carbon $\mathbf{( \% )}$ & Redox (\%) \\
\hline MG1655 & $0.66 \pm 0.02$ & 97 & 101 \\
MG1655 $\Delta$ arcA & $0.60 \pm 0.01$ & 96 & 94 \\
MG1655 $\Delta$ iclR & $0.61 \pm 0.02$ & 95 & 95 \\
MG1655 $\Delta$ arcA $\Delta$ iclR & $0.44 \pm 0.03$ & 99 & 101 \\
BL21(DE3) & $0.59 \pm 0.02$ & 93 & 99 \\
\hline
\end{tabular}

Table 1. Average maximum growth rate, carbon balance and redox balance for batch cultures of the investigated strains

The $\operatorname{arc} A$ and $i c l R$ single knockouts strains have a slightly lower maximum growth rate. In contrary the combined arcA-iclR double knockout strain in E. coli MG1655 exhibits a substantial reduction of $38 \%$ in $\mu_{\max }$. Fig. 3 shows the effect of these mutations on various product yields under abundant glucose conditions. The corresponding average redox and carbon balances close very well (Table 1 ).

Product yields in c-mole/c-mole glucose for E. coli MG1655, MG1655 $\Delta \operatorname{arcA,~MG1655~} \Delta i c l R$, MG1655 $\triangle \operatorname{arc} A \triangle i c l R$ and BL21 under glucose abundant conditions. Oxygen yield is shown as a positive number for a clear representation, but $\mathrm{O}_{2}$ is actually consumed during experiments. The values represented in the graph are the average of at least two separate experiments and the errors are standard deviations calculated on the yields.

Both the $\operatorname{arc} A$ and $i c l R$ knockout strains show an increased biomass yield in E. coli MG1655. When combining these deletions in E. coli MG1655 the yield is further increased to $0.063 \pm$ $0.01 \mathrm{c}-\mathrm{mole} / \mathrm{c}-\mathrm{mole}$ glucose, which approximates the theoretical biomass yield of $0.65 \mathrm{c}-$ mole/c-mole glucose (assuming a P/O-ratio of 1.4) (Varma et al., 1993a; Varma et al., 1993b) and slightly higher compared to the E. coli BL21(DE3) wild-type. The higher biomass yield in E. coli MG1655 $\triangle \operatorname{arcA} \triangle i c l R$ is accompanied by a $70 \%$ and $16 \%$ reduction in acetate and $\mathrm{CO}_{2}$ yields, respectively. This reduction in $\mathrm{CO}_{2}$ yield could indicate that the glyoxylate pathway is more active in the double knock-out mutant as is observed in E. coli BL21 (Noronha et al., 2000).

The deletion of local transcriptional regulator $i c l R$ reduces the acetate formation with $50 \%$ in E. coli MG1655. When the global transcriptional regulator $\operatorname{arcA}$ is additionally deleted, the acetate yield is even further decreased to a comparable value of $E$. coli BL21(DE3). 


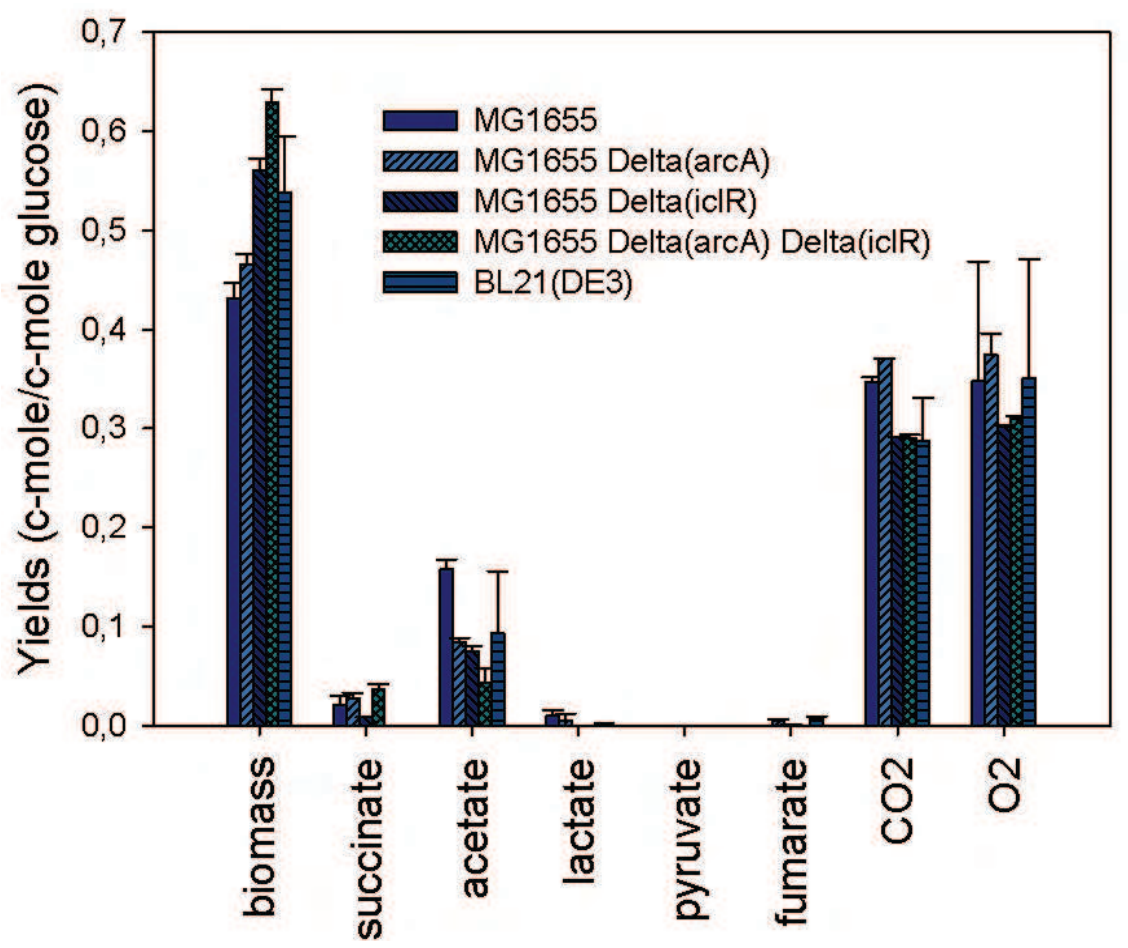

Fig. 3. Product yields of the different E. coli strains in batch cultures.

${ }^{13} \mathrm{C}$-metabolic flux analysis confirmed our hypothesis that the deletion of both $\operatorname{arcA}$ and $i c l R$ in E. coli MG1655 alters central metabolism fluxes profoundly (Fig. 4). A higher flux at the entrance of the TCA cycle was observed due to $\operatorname{arcA}$ deletion resulting in a reduced production of acetate and less carbon loss. Due to the $i c l R$ deletion, the glyoxylate pathway is activated resulting in a redirection of $30 \%$ of the isocitrate molecules directly to succinate and malate without $\mathrm{CO}_{2}$ production.

Moreover, similar central metabolic fluxes were observed in the combined $\operatorname{arcA}$-iclR double knockout in E. coli MG1655 as in E. coli BL21(DE3). These results suggest that the expression levels of $\operatorname{arcA}$ and $i c l R$ are low in E. coli BL21. We could confirm that deletion of both $\operatorname{arcA}$ and iclR in E. coli BL21 had no severe implications on the phenotype (Waegeman et al., 2011c). Only a slight decrease in growth rate was observed. Thus, this proves that ArcA and IclR are poorly active in E. coli BL21 whereas in E. coli K12 both regulators play an important role. This can be explained by mutations in the promoter region of $i c l R$ and a less efficient codon usage of arcA in E. coli BL21 (Waegeman et al., 2011a).

Thus, by deletion of a local and global transcriptional regulator, ArcA and IclR respectively, we could mimic the physiological and metabolic properties of E. coli BL21 in an E. coli K12 strain. Furthermore, only a small part of the tremendously elevated biomass yield was attributed to increased glycogen content (Waegeman et al., 2011a) making this strain an attractive candidate for recombinant protein production. 


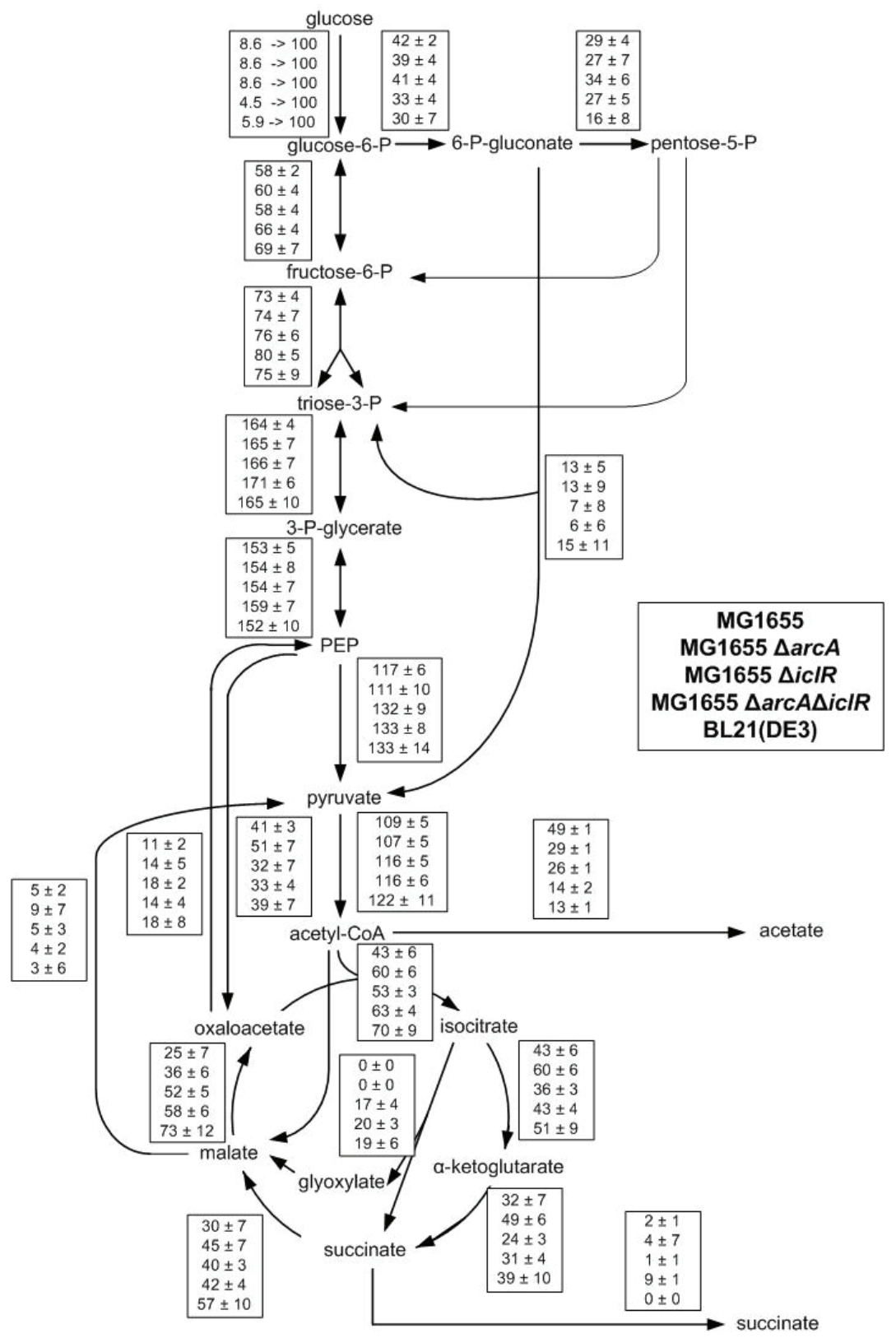

Fig. 4. Metabolic Flux distribution in E. coli MG1655, its derivate single knockout strains $\triangle \operatorname{arc} A$ and $\triangle i c l R$, and the double knockout strain $\triangle \operatorname{arc} A \Delta i c l R$, and E. coli BL21 cultivated in glucose abundant conditions. More specific details about the metabolic flux calculations can be found in (Waegeman et al., 2011a) 


\subsection{Escherichia coli MG1655 $\Delta a r c A \Delta i c / R$ as potential candidate for recombinant protein production}

Our previous research has shown that similar metabolic and physiological characteristics as E. coli BL21 can be achieved in E. coli $\mathrm{K} 12$ by combined deletion of the global transcriptional regulator ArcA and the local transcriptional regulator IclR.

To investigate whether these metabolic alterations in E. coli MG1655 also beneficially influence recombinant protein production, we compared the recombinant protein production of the metabolically engineered strain to E. coli BL21(DE3) using GFP (Green Fluorescent Protein) as a biomarker (Fig. 5).

Batch cultures were performed in 2L stirred tank bioreactors. Yields are calculated by dividing GFP and biomass concentrations during the cultivation phase when biomass concentrations are higher than $2 \mathrm{gL}^{-1}$. The values represented in the graph are the average of at least two separate experiments and the errors are the standard deviations calculated on the yields.

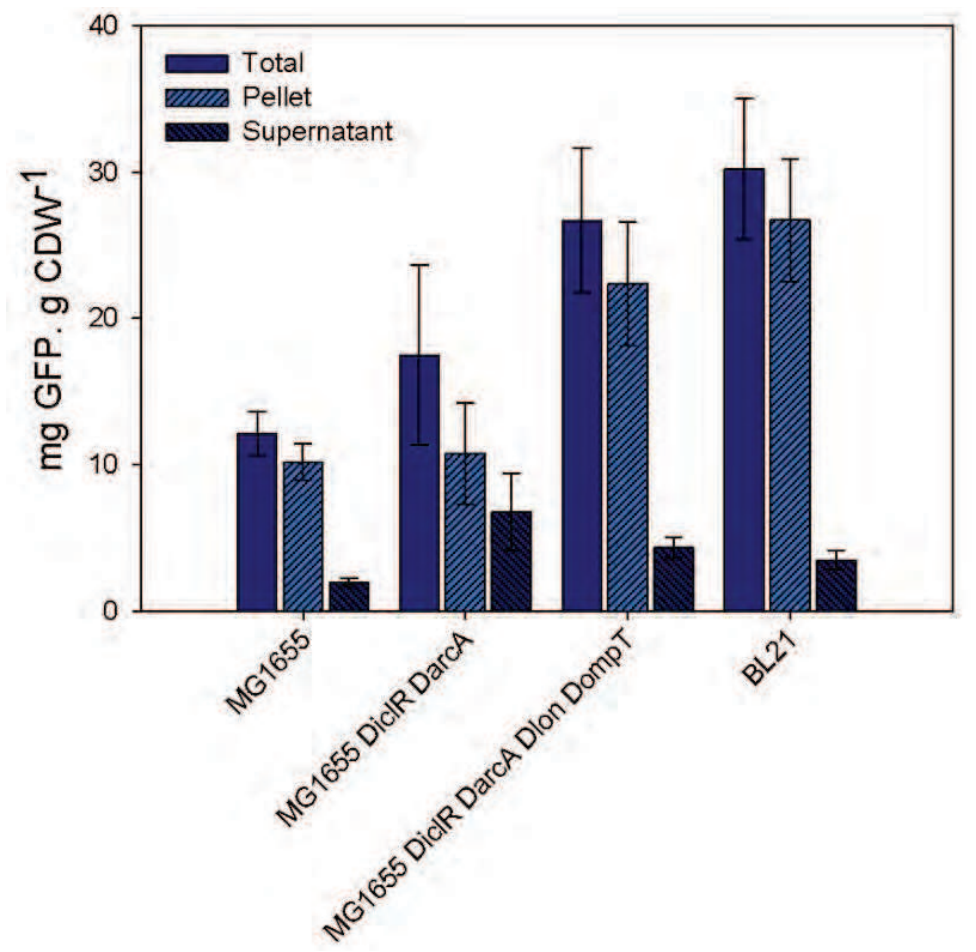

Fig. 5. Overall GFP yields of the different strains in batch cultures.

To our regret, the combined $\operatorname{arcA-iclR}$ double knockout mutant did not perform as we anticipated. Although the increased biomass yield and decreased acetate yield in the double knockout beneficially influence recombinant protein production as a higher GFP yield was observed to its wild type E. coli MG1655 (30\% increase in the double knockout strain), still a 
striking difference of more than $40 \%$ was detected compared to E. coli Bl21. Additionally, we observed that at higher cell densities (>2gL-1 CDW) the GFP concentrations decreases again suggesting proteases activity (Waegeman et al., 2011b).

Proteases play an important role in the degradation of foreign proteins (Gottesman \& Maurizi, 1992) and it is generally believed that recombinant proteins are better produced in E. coli BL21 and his derivates because these strains lack the cytoplasmic ATP-dependent protease Lon (Gottesman, 1989) and the periplasmic OmpT (Gottesman, 1996).

Although also other proteases are known for the degradation of proteins, but in a lesser extent towards recombinant proteins (Jürgen et al., 2010) and since E. coli BL21 lacks the proteases Lon and OmpT, these proteases were also deleted in the E. coli MG1655 $\triangle a r c A$ $\Delta i c l R$ strain.

The additional deletion of the proteases Lon and OmpT, resulting in the quadruple knockout strain E. coli MG1655 $\triangle a r c A \Delta i c l R \Delta$ lon $\Delta o m p T$, could impede the breakdown of GFP at higher cell densities. The GFP yield obtained at the end of the glucose growth phase in bioreactor experiments approximates the GFP yield of E. coli BL21 (DE3).

\section{Conclusion}

To date, recombinant protein production has evolved to one of the most important branches in modern biotechnology, representing a billion-dollar business, both in the production of biopharmaceuticals and industrial enzymes. Although many organisms have been used as host, Escherichia coli is predominantly utilised as microbial host, representing $30 \%$ of the bioprocesses in both industries.

Although, E. coli strains are popular because they are fast growers, metabolically and genetically well characterised, and many molecular tools are available, these strains display several drawbacks. Besides problems related to stress response, post-transcriptional modification and secretion of recombinant proteins, a major drawback is the formation of acetate in aerobic cultures which retards growth and impedes protein production.

Logically, many endeavours have been reported to decrease acetate formation and increase recombinant protein production in this host. However, among the different $E$. coli strains, $E$. coli BL21 and his derivates show a significant low acetate formation compared to E. coli K12 strains, making BL21 a standard host in industrial recombinant protein production bioprocesses. Though, E. coli BL21 is not the optimal host due to plasmid instability and, until recently, unknown genome sequence making genetic modifications challenging.

Traditionally, acetate formation in E. coli K12 strains is tackled by blocking the acetate pathways or avoiding overflow metabolism through limiting the glucose uptake rate or redirecting the fluxes around the bottleneck, the phosphoenolpyruvate-pyruvateoxaloacetate node. Alternatively, we propose to copy similar physiological and metabolic properties of E. coli BL21 in E. coli K12. This was achieved by combined deletion of the global transcriptional regulator ArcA and the local regulator IclR. Albeit this metabolically engineered E. coli K12 derivate displayed higher biomass yield and lower acetate yield resulting in a substantially increase in recombinant protein yield, the protein yield was still considerably lower than the yield observed in E. coli BL21. This difference in recombinant 
protein production is caused by proteolytic activity in E. coli $\mathrm{K} 12$, which does not occur in $E$. coli BL21 due to absence of the proteases Lon and OmpT. Additional deletion of these proteases in our combined $\operatorname{arcA-icl} R$ double knockout strain, hampered this proteolytic activity yielding recombinant protein levels similar to E. coli BL21.

In conclusion, by deleting only four genes, i.e. $\operatorname{arc} A$, $i c l R$, lon, and $\operatorname{omp} T$ it was possible to mimic the phenotype of E. coli BL21 in E. coli K12. The metabolically engineered quadruple knockout strain exhibited not only a tremendous increase in biomass yield and severe decrease in acetate yield, the recombinant protein production increased by a factor 2 , resulting in a strain that can compete with E. coli BL21 for the industrial production of recombinant proteins. These results are incentive to further optimization of $E$. coli as microbial host making $E$. coli an often-chosen host in industrial bioprocesses.

\section{Acknowledgment}

The research of Hendrik Waegeman was financially supported by the Special Research Fund (BOF) of Ghent University

\section{References}

Abdallah, A.M., van Pittius, N.C.G., Champion, P.A.D., Cox, J., Luirink, J., VandenbrouckeGrauls, C.M.J.E., Appelmelk, B.J.\& Bitter, W. (2007). Type VII secretionmycobacteria show the way. Nat Rev Microbiol, Vol. 5, pp. 883-891

Abu-Qarn, M., Eichler, J.\& Sharon, N. (2008). Not just for Eukarya anymore: protein glycosylation in Bacteria and Archaea. Curr Opin Struct Biol, Vol. 18, pp. 544-550

Akesson, M., Hagander, P.\& Axelsson, J.P. (2001a). Avoiding acetate accumulation in Escherichia coli cultures using feedback control of glucose feeding. Biotechnology and Bioengineering, Vol. 73, pp. 223-230

Akesson, M., Hagander, P.\& Axelsson, J.P. (2001b). Probing control of fed-batch cultivations: analysis and tuning. Control Engineering Practice, Vol. 9, pp. 709-723

Akesson, M., Karlsson, E.N., Hagander, P., Axelsson, J.P.\& Tocaj, A. (1999). On-line detection of acetate formation in Escherichia coli cultures using dissolved oxygen responses to feed transients. Biotechnology and Bioengineering, Vol. 64, pp. 590-598

Alexeeva, S., Hellingwerf, K.J.\& de Mattos, M.J.T. (2003). Requirement of ArcA for redox regulation in Escherichia coli under microaerobic but not anaerobic or aerobic conditions. J Bacteriol, Vol. 185, pp. 204-209

Andersen, K.B.\& von Meyenburg, K. (1980). Are growth rates of Escherichia coli in batch cultures limited by respiration? J Bacteriol, Vol. 144, pp. 114-123

Bentley, W.E., Mirjalili, N., Andersen, D.C., Davis, R.H.\& Kompala, D.S. (1990). Plasmidencoded protein: the principal factor in the "metabolic burden" associated with recombinant bacteria. Biotechnol Bioeng, Vol. 35, pp. 668-681

Chen, X., Cen, P.\& Chen, J. (2005). Enhanced production of human epidermal growth factor by a recombinant Escherichia coli integrated with in situ exchange of acetic acid by macroporous ion-exchange resin. Journal of Bioscience and Bioengineering, Vol. 100, pp. 579-581

Choi, J.H.\& Lee, S.Y. (2004). Secretory and extracellular production of recombinant proteins using Escherichia coli. Appl Microbiol Biotechnol, Vol. 64, pp. 625-635 
Chou, C.H., Bennett, G.N.\& San, K.Y. (1994). Effect of modified glucose uptake using genetic engineering techniques on high-level recombinant protein production in Escherichia coli dense cultures. Biotechnol Bioeng, Vol. 44, pp. 952-960

Chou, C.P. (2007). Engineering cell physiology to enhance recombinant protein production in Escherichia coli. Appl Microbiol Biotechnol, Vol. 76, pp. 521-532

Cohen, S.N., Chang, A.C., Boyer, H.W.\& Helling, R.B. (1973). Construction of biologically functional bacterial plasmids in vitro. Proc Natl Acad Sci U S A, Vol. 70, pp. 32403244

Contiero, J., Beatty, C., Kumari, S., DeSanti, C., Strohl, W.\& Wolfe, A. (2000). Effects of mutations in acetate metabolism on high-cell-density growth of Escherichia coli. J Ind Microbiol Biotechnol, Vol. 24, pp. 421-430

Cortay, J.C., Nègre, D., Galinier, A., Duclos, B., Perrière, G.\& Cozzone, A.J. (1991). Regulation of the acetate operon in Escherichia coli: purification and functional characterization of the IclR repressor. EMBO J, Vol. 10, pp. 675-679

Cozzone, A.J. (1998). Regulation of acetate metabolism by protein phosphorylation in enteric bacteria. Annu Rev Microbiol, Vol. 52, pp. 127-164

De Anda, R., Lara, A.R., Hernández, V., Hernández-Montalvo, V., Gosset, G., Bolívar, F.\& Ramírez, O.T. (2006). Replacement of the glucose phosphotransferase transport system by galactose permease reduces acetate accumulation and improves process performance of Escherichia coli for recombinant protein production without impairment of growth rate. Metab Eng, Vol. 8, pp. 281-290

de Marco, A. (2009). Strategies for successful recombinant expression of disulfide bonddependent proteins in Escherichia coli. Microb Cell Fact, Vol. 8, pp. 26

De Mey, M., Lequeux, G.J., Beauprez, J.J., Maertens, J., Van Horen, E., Soetaert, W.K., Vanrolleghem, P.A.\& Vandamme, E.J. (2007a). Comparison of different strategies to reduce acetate formation in Escherichia coli. Biotechnol Prog, Vol. 23, pp. 1053-1063

De Mey, M., Lequeux, G.J., Beauprez, J.J., Maertens, J., Waegeman, H.J., Van Bogaert, I.N., Foulquie-Moreno, M.R., Charlier, D., Soetaert, W.K., Vanrolleghem, P.A.\& Vandamme, E.J. (2010). Transient metabolic modeling of Escherichia coli MG1655 and MG1655 DeltaackA-pta, DeltapoxB Deltapppc ppc-p37 for recombinant betagalactosidase production. J Ind Microbiol Biotechnol, Vol. 37, pp. 793-803

De Mey, M., Maeseneire, S.D., Soetaert, W.\& Vandamme, E. (2007b). Minimizing acetate formation in E. coli fermentations. J Ind Microbiol Biotechnol, Vol. 34, pp. 689-700

Demain, A.L.\& Vaishnav, P. (2009). Production of recombinant proteins by microbes and higher organisms. Biotechnol Adv, Vol. 27, pp. 297-306

Diaz-Ricci, J.C., Regan, L.\& Bailey, J.E. (1991). Effect of alteration of the acetic acid synthesis pathway on the fermentation pattern of Escherichia coli. Biotechnol Bioeng, Vol. 38, pp. 1318-1324

Dittrich, C.R., Vadali, R.V., Bennett, G.N.\& San, K.-Y. (2005). Redistribution of metabolic fluxes in the central aerobic metabolic pathway of E. coli mutant strains with deletion of the ackA-pta and poxB pathways for the synthesis of isoamyl acetate. Biotechnol Prog, Vol. 21, pp. 627-631

Dong, H., Nilsson, L.\& Kurland, C.G. (1995). Gratuitous overexpression of genes in Escherichia coli leads to growth inhibition and ribosome destruction. J Bacteriol, Vol. 177, pp. 1497-1504 
Durocher, Y.\& Butler, M. (2009). Expression systems for therapeutic glycoprotein production. Curr Opin Biotechnol, Vol. 20, pp. 700-707

Eiteman, M.A.\& Altman, E. (2006). Overcoming acetate in Escherichia coli recombinant protein fermentations. Trends in Biotechnology, Vol. 24, pp. 530-533

El-Mansi, E.M.\& Holms, W.H. (1989). Control of carbon flux to acetate excretion during growth of Escherichia coli in batch and continuous cultures. J Gen Microbiol, Vol. 135, pp. 2875-2883

El-Mansi, M., Cozzone, A.J., Shiloach, J.\& Eikmanns, B.J. (2006). Control of carbon flux through enzymes of central and intermediary metabolism during growth of Escherichia coli on acetate. Curr Opin Microbiol, Vol. 9, pp. 173-179

Farmer, W.R.\& Liao, J.C. (1997). Reduction of aerobic acetate production by Escherichia coli. Appl Environ Microbiol, Vol. 63, pp. 3205-3210

Ferrer-Miralles, N., Domingo-Espín, J., Corchero, J.L., Vázquez, E.\& Villaverde, A. (2009). Microbial factories for recombinant pharmaceuticals. Microb Cell Fact, Vol. 8, pp. 17

Fischer, E.\& Sauer, U. (2003). A novel metabolic cycle catalyzes glucose oxidation and anaplerosis in hungry Escherichia coli. J Biol Chem, Vol. 278, pp. 46446-46451

Fisher, A.C., Haitjema, C.H., Guarino, C., Çelik, E., Endicott, C.E., Reading, C.A., Merritt, J.H., Ptak, A.C., Zhang, S.\& DeLisa, M.P. (2011). Production of secretory and extracellular N-linked glycoproteins in Escherichia coli. Appl Environ Microbiol, Vol. 77, pp. 871-881

Fuchs, C., Koster, D., Wiebusch, S., Mahr, K., Eisbrenner, G.\& Markl, H. (2002 ). Scale-up of dialysis fermentation for high cell density cultivation of Escherichia coli. Journal of Biotechnology, Vol. 93, pp. 243-251

Gill, R.T., Valdes, J.J.\& Bentley, W.E. (2000). A comparative study of global stress gene regulation in response to overexpression of recombinant proteins in Escherichia coli. Metab Eng, Vol. 2, pp. 178-189

Global Industry Analysts, I. (February 09, 2011). Global Industrial Enzymes, In: PRWeb, July 20, 2011, Available from:

http://www.prweb.com/releases/industrial_enzymes/proteases_carbohydrases/ prweb8121185.htm.

Gottesman, S. (1984). Bacterial regulation: global regulatory networks. Annu Rev Genet, Vol. 18, pp. $415-441$

Gottesman, S. (1989). Genetics of proteolysis in Escherichia coli. Annu Rev Genet, Vol. 23, pp. 163-198

Gottesman, S. (1996). Proteases and their targets in Escherichia coli. Annu Rev Genet, Vol. 30, pp. $465-506$

Gottesman, S.\& Maurizi, M.R. (1992). Regulation by proteolysis: energy-dependent proteases and their targets. Microbiol Rev, Vol. 56, pp. 592-621

Hodgson, J. (1994). The changing bulk biocatalyst market. Nat Biotechnol, Vol. 12, pp. 789790

Hoffmann, F.\& Rinas, U. (2004). Stress induced by recombinant protein production in Escherichia coli. Adv Biochem Eng Biotechnol, Vol. 89, pp. 73-92

Holms, W.H. (1986). The central metabolic pathways of Escherichia coli: relationship between flux and control at a branch point, efficiency of conversion to biomass, and excretion of acetate. Curr Top Cell Regul, Vol. 28, pp. 69-105 
Iuchi, S.\& Lin, E.C. (1988). arcA (dye), a global regulatory gene in Escherichia coli mediating repression of enzymes in aerobic pathways. Proc Natl Acad Sci U S A, Vol. 85, pp. 1888-1892

Iuchi, S., Matsuda, Z., Fujiwara, T.\& Lin, E.C. (1990). The arcB gene of Escherichia coli encodes a sensor-regulator protein for anaerobic repression of the arc modulon. Mol Microbiol, Vol. 4, pp. 715-727

Jensen, E.B.\& Carlsen, S. (1990). Production of recombinant human growth hormone in Escherichia coli: expression of different precursors and physiological effects of glucose, acetate, and salts. Biotechnol Bioeng, Vol. 36, pp. 1-11

Jong, W.S.P., Saurí, A.\& Luirink, J. (2010). Extracellular production of recombinant proteins using bacterial autotransporters. Curr Opin Biotechnol, Vol. 21, pp. 646-652

Jürgen, B., Breitenstein, A., Urlacher, V., Büttner, K., Lin, H., Hecker, M., Schweder, T.\& Neubauer, P. (2010). Quality control of inclusion bodies in Escherichia coli. Microb Cell Fact, Vol. 9, pp. 41

Keseler, I.M., Collado-Vides, J., Santos-Zavaleta, A., Peralta-Gil, M., Gama-Castro, S., Muniz-Rascado, L., Bonavides-Martinez, C., Paley, S., Krummenacker, M., Altman, T., Kaipa, P., Spaulding, A., Pacheco, J., Latendresse, M., Fulcher, C., Sarker, M., Shearer, A.G., Mackie, A., Paulsen, I., Gunsalus, R.P.\& Karp, P.D. (2011). EcoCyc: a comprehensive database of Escherichia coli biology. Nucleic Acids Research, Vol. 39, pp. D583-D590

Ko, C.-H., Tsai, C.-H., Lin, P.-H., Chang, K.-C., Tu, J., Wang, Y.-N.\& Yang, C.-Y. (2010). Characterization and pulp refining activity of a Paenibacillus campinasensis cellulase expressed in Escherichia coli. Bioresour Technol, Vol.,

Kurland, C.G.\& Dong, H. (1996). Bacterial growth inhibition by overproduction of protein. Mol Microbiol, Vol. 21, pp. 1-4

Lotti, M., Porro, D.\& Srienc, F. (2004). Recombinant proteins and host cell physiology. J Biotechnol, Vol. 109, pp. 1-2

Maharjan, R.P., Yu, P.-L., Seeto, S.\& Ferenci, T. (2005). The role of isocitrate lyase and the glyoxylate cycle in Escherichia coli growing under glucose limitation. Res Microbiol, Vol. 156, pp. 178-183

Makrides, S.C. (1996). Strategies for achieving high-level expression of genes in Escherichia coli. Microbiol Rev, Vol. 60, pp. 512-538

March, J.C., Eiteman, M.A.\& Altman, E. (2002). Expression of an anaplerotic enzyme, pyruvate carboxylase, improves recombinant protein production in Escherichia coli. Appl Environ Microbiol, Vol. 68, pp. 5620-5624

Martinez-Antonio, A.\& Collado-Vides, J. (2003). Identifying global regulators in transcriptional regulatory networks in bacteria. Curr Opin Microbiol, Vol. 6, pp. 482-489

Nakano, K., Rischke, M., Sato, S.\& Märkl, H. (1997). Influence of acetic acid on the growth of Escherichia coli K12 during high-cell-density cultivation in a dialysis reactor. Appl Microbiol Biotechnol, Vol. 48, pp. 597-601

Noack, D., Roth, M., Geuther, R., Muller, G., Undisz, K., Hoffmeier, C.\& Gaspar, S. (1981). Maintenance and genetic stability of vector plasmids pBR322 and pBR325 in Escherichia coli K12 strains grown in a chemostat. Mol Gen Genet, Vol. 184, pp. 121124 
Noronha, S.B., Yeh, H.J., Spande, T.F.\& Shiloach, J. (2000). Investigation of the TCA cycle and the glyoxylate shunt in Escherichia coli BL21 and JM109 using (13)C-NMR/MS. Biotechnol Bioeng, Vol. 68, pp. 316-327

Parsell, D.A.\& Sauer, R.T. (1989). Induction of a heat shock-like response by unfolded protein in Escherichia coli: dependence on protein level not protein degradation. Genes Dev, Vol. 3, pp. 1226-1232

Perrenoud, A.\& Sauer, U. (2005). Impact of global transcriptional regulation by ArcA, ArcB, Cra, Crp, Cya, Fnr, and Mlc on glucose catabolism in Escherichia coli. J Bacteriol, Vol. 187, pp. 3171-3179

Phue, J.-N., Noronha, S.B., Ritabrata, Wolfe, A.J.\& Shiloach, J. (2005). Glucose metabolism at high density growth of E. coli $\mathrm{B}$ and E. coli $\mathrm{K}$ : differences in metabolic pathways are responsible for efficient glucose utilization in E. coli B as determined by microarrays and Northern blot analyses. Biotechnol Bioeng, Vol. 90, pp. 805-820

Rittinger, K., Negre, D., Divita, G., Scarabel, M., Bonod-Bidaud, C., Goody, R.S., Cozzone, A.J.\& Cortay, J.C. (1996). Escherichia coli isocitrate dehydrogenase kinase/phosphatase. Eur J Biochem, Vol. 237, pp. 247-254

Ryu, K., Kim, K.-H., Yoo, S.-Y., Lee, E.-Y., Lim, K.-H., Min, M.-K., Kim, H., Choi, S.I.\& Seong, B.L. (2010). Production and characterization of active hepatitis C virus RNAdependent RNA polymerase. Protein Expr Purif, Vol. 71, pp. 147-152

Sahdev, S., Khattar, S.K.\& Saini, K.S. (2008). Production of active eukaryotic proteins through bacterial expression systems: a review of the existing biotechnology strategies. Mol Cell Biochem, Vol. 307, pp. 249-264

Salmon, K.A., Hung, S.-p., Steffen, N.R., Krupp, R., Baldi, P., Hatfield, G.W.\& Gunsalus, R.P. (2005). Global gene expression profiling in Escherichia coli K12: effects of oxygen availability and ArcA. J Biol Chem, Vol. 280, pp. 15084-15096

Shiloach, J., Kaufman, J., Guillard, A.S.\& Fass, R. (1996). Effect of glucose supply strategy on acetate accumulation, growth, and recombinant protein production by Escherichia coli BL21 (\$\lambda\$DE3) and Escherichia coli JM109. Biotechnol Bioeng, Vol. 49, pp. 421-428

Siguenza, R., Flores, N., Hernandez, G., Mart \'inez, A., Bolivar, F.\& Valle, F. (1999). Kinetic characterization in batch and continuous culture of Escherichia coli mutants affected in phosphoenolpyruvate metabolism: differences in acetic acid production. World J Microbiol Biotechnol, Vol. 15, pp. 587-592

Striedner, G., Pfaffenzeller, I., Markus, L., Nemecek, S., Grabherr, R.\& Bayer, K. (2010). Plasmid-free T7-based Escherichia coli expression systems. Biotechnol Bioeng, Vol. 105, pp. 786-794

Szymanski, C.M., Yao, R., Ewing, C.P., Trust, T.J.\& Guerry, P. (1999). Evidence for a system of general protein glycosylation in Campylobacter jejuni. Mol Microbiol, Vol. 32, pp. 1022-1030

Terpe, K. (2006). Overview of bacterial expression systems for heterologous protein production: from molecular and biochemical fundamentals to commercial systems. Appl Microbiol Biotechnol, Vol. 72, pp. 211-222

Tseng, T.-T., Tyler, B.M.\& Setubal, J.C. (2009). Protein secretion systems in bacterial-host associations, and their description in the Gene Ontology. BMC Microbiol, Vol. 9, pp. S2 
Varma, A., Boesch, B.W.\& Palsson, B.O. (1993a). Biochemical production capabilities of Escherichia coli. Biotechnol Bioeng, Vol. 42, pp. 59-73

Varma, A., Boesch, B.W.\& Palsson, B.O. (1993b). Stoichiometric interpretation of Escherichia coli glucose catabolism under various oxygenation rates. Appl Environ Microbiol, Vol. 59, pp. 2465-2473

Ventura, S.\& Villaverde, A. (2006). Protein quality in bacterial inclusion bodies. Trends Biotechnol, Vol. 24, pp. 179-185

Wacker, M., Linton, D., Hitchen, P.G., Nita-Lazar, M., Haslam, S.M., North, S.J., Panico, M., Morris, H.R., Dell, A., Wren, B.W.\& Aebi, M. (2002). N-linked glycosylation in Campylobacter jejuni and its functional transfer into E. coli. Science, Vol. 298, pp. 1790-1793

Waegeman, H., Beauprez, J., Moens, H., Maertens, J., De Mey, M., Foulquie-Moreno, M.R., Heijnen, J.J., Charlier, D.\& Soetaert, W. (2011a). Effect of iclR and arcA knockouts on biomass formation and metabolic fluxes in Escherichia coli $\mathrm{K} 12$ and its implications on understanding the metabolism of Escherichia coli BL21 (DE3). BMC Microbiol, Vol. 11, pp. 70

Waegeman, H., De Lausnay, S., Beauprez, J., Maertens, J., De Mey, M.\& Soetaert, W. (2011b). Increasing recombinant protein production in Escherichia coli K12 through metabolic engineering. New Biotechnology, submitted

Waegeman, H., Maertens, J., Beauprez, J., De Mey, M.\& Soetaert, W. (2011c). Effect of iclR and $\operatorname{arcA}$ deletion on physiology and metabolic fluxes in Escherichia coli BL21(DE3). Biotechnology Progress, in press

Waegeman, H.\& Soetaert, W. (2011). Increasing recombinant protein production in Escherichia coli through metabolic and genetic engineering. Journal of Industrial Microbiology and Biotechnology, accepted

Walsh, G. (2010). Post-translational modifications of protein biopharmaceuticals. Drug Discov Today, Vol. 15, pp. 773-780

Wong, M.S., Wu, S., Causey, T.B., Bennett, G.N.\& San, K.-Y. (2008). Reduction of acetate accumulation in Escherichia coli cultures for increased recombinant protein production. Metab Eng, Vol. 10, pp. 97-108

Yamamoto, K.\& Ishihama, A. (2003). Two different modes of transcription repression of the Escherichia coli acetate operon by IclR. Mol Microbiol, Vol. 47, pp. 183-194

Yang, Y.T., Aristidou, A.A., San, K.Y.\& Bennett, G.N. (1999). Metabolic flux analysis of Escherichia coli deficient in the acetate production pathway and expressing the Bacillus subtilis acetolactate synthase. Metab Eng, Vol. 1, pp. 26-34 


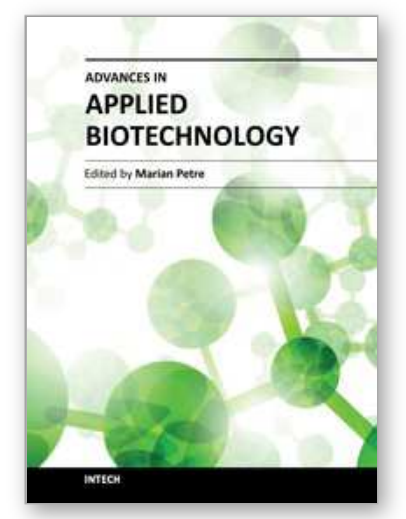

\author{
Advances in Applied Biotechnology \\ Edited by Prof. Marian Petre
}

ISBN 978-953-307-820-5

Hard cover, 288 pages

Publisher InTech

Published online 20, January, 2012

Published in print edition January, 2012

Biotechnology is the scientific field of studying and applying the most efficient methods and techniques to get useful end-products for the human society by using viable micro-organisms, cells, and tissues of plants or animals, or even certain functional components of their organisms, that are grown in fully controlled conditions to maximize their specific metabolism inside fully automatic bioreactors. It is very important to make the specific difference between biotechnology as a distinct science of getting valuable products from molecules, cells or tissues of viable organisms, and any other applications of bioprocesses that are based on using the whole living plants or animals in different fields of human activities such as bioremediation, environmental protection, organic agriculture, or industrial exploitation of natural resources. The volume Advances in Applied Biotechnology is a scientific book containing recent advances of selected research works that are ongoing in certain biotechnological applications. Fourteen chapters divided in four sections related to the newest biotechnological achievements in environmental protection, medicine and health care, biopharmaceutical producing, molecular genetics, and tissue engineering are presented.

\title{
How to reference
}

In order to correctly reference this scholarly work, feel free to copy and paste the following:

Hendrik Waegeman and Marjan De Mey (2012). Increasing Recombinant Protein Production in E. coli by an Alternative Method to Reduce Acetate, Advances in Applied Biotechnology, Prof. Marian Petre (Ed.), ISBN: 978-953-307-820-5, InTech, Available from: http://www.intechopen.com/books/advances-in-appliedbiotechnology/increasing-recombinant-protein-production-in-e-coli-by-an-alternative-method-to-reduce-acetate

\section{INTECH}

open science | open minds

\section{InTech Europe}

University Campus STeP Ri

Slavka Krautzeka 83/A

51000 Rijeka, Croatia

Phone: +385 (51) 770447

Fax: +385 (51) 686166

www.intechopen.com

\section{InTech China}

Unit 405, Office Block, Hotel Equatorial Shanghai

No.65, Yan An Road (West), Shanghai, 200040, China 中国上海市延安西路65号上海国际贵都大饭店办公楼 405 单元

Phone: +86-21-62489820

Fax: +86-21-62489821 
(C) 2012 The Author(s). Licensee IntechOpen. This is an open access article distributed under the terms of the Creative Commons Attribution 3.0 License, which permits unrestricted use, distribution, and reproduction in any medium, provided the original work is properly cited. 